\title{
TINJAUAN YURIDIS TERHADAP PENYELESAIAN WANPRESTASI DALAM PEMBAYARAN ANGSURAN PADA LEMBAGA KEUANGAN MIKRO SYARIAH
}

\author{
Junaidi \\ Program Studi Ilmu Hukum Fakultas Hukum \\ Universitas Jabal Ghafur
}

\begin{abstract}
ABSTRAK
Salah satu lembaga keuangan non perbankan dewasa ini yang banyak tumbuh dalam masyarakat adalah Lembaga Keuangan Mikro (LKM). LKM adalah sebuah lembaga yang kegiatannya memberikan layanan keuangan atau permodalan kepada masyarakat kecil yang tidak dilayani oleh lembaga perbankan. LKM tersebut keberadaannya dimaksudkan untuk membantu perekonomian umat Islam dengan pemberian pembiayaan. Ketentuan pemberian pembiayaan ini juga berpedoman pada ketentuan Undang-undang Nomor 17 Tahun 2012 tentang Perbankan Syariah. yang berbunyi : "Pembiayaan berdasarkan prinsip syariah adalah penyediaan uang, barang atau tagihan yang dapat dipersamakan dengan itu, berdasarkan persetujuan atau kesepakatan antara lembaga keuangan dengan pihak lain yang mewajibkan pihak yang dibiayai untuk mengembalikan uang atau tagihan tersebut setelah jangka waktu tertentu dengan imbalan bagi hasil.Bantuan pinjaman modal usaha untuk masyarakat yang disalurkan melalui LKM tersebut atau biasanya disebut Bantuan Langsung pada Masyarakat (BLM). Bantuan langsung pada masyarakat yang diberikan sebagai pinjaman modal usaha, bisa digunakan untuk modal kerja (belanja bahan-bahan/barang dagangan) atau investasi (belanja alat-alat atau sarana yang digunakan untuk usaha). Bantuan tersebut harus bergulir yang harus dikembalikan kepada LKM karena masih banyak masyarakat lain yang membutuhkan, sementara jumlah bantuan sangat terbatas.
\end{abstract}

Kata kunci : Wanprestasi

\section{PENDAHULUAN}

Dalam mengelola kegiatan usaha yang bcrsifat produktif diperlukan dukungan modal yang memadai. Namun dalam praktek seringkali permasalahan modal menjadi batu ganjalan bagi para pelaksana. Oleh karena itu, untuk memperoleh modal yang cukup masyarakat berusaha mendapatkan tambahan dari pihak lain. Salah satu sumber untuk mendapatkan modal kerja tersebut adalah dari lembaga perbankan maupun lembaga non perbankan.

Salah satu lembaga keuangan non perbankan dewasa ini yang banyak tumbuh dalam masyarakat adalah Lembaga Keuangan Mikro (LKM). LKM adalah sebuah lembaga yang kegiatannya memberikan layanan keuangan atau permodalan kepada masyarakat kecil yang tidak dilayani oleh lembaga perbankan. $\begin{array}{crr}\text { LKM } & \text { tersebut } & \text { keberadaannya } \\ \text { dimaksudkan } & \text { untuk } & \text { membantu }\end{array}$ perekonomian umat Islam dengan pemberian pembiayaan. Ketentuan pemberian pembiayaan ini juga berpedoman pada ketentuan Undang-undang Nomor 17 Tahun 2012 tentang Perbankan Syariah. yang berbunyi : "Pembiayaan berdasarkan prinsip syariah adalah penyediaan uang, barang atau tagihan yang dapat dipersamakan dengan itu, berdasarkan persetujuan atau kesepakatan antara lembaga keuangan dengan pihak lain yang mewajibkan pihak yang dibiayai untuk mengembalikan uang atau tagihan tersebut setelah $\mathrm{j}$ angka waktu tertentu dengan imbalan bagi hasil".

LKM yang berbadan hukum koperasi yang tunduk pada ketentuan pasal 1 angka 1 Undang-undang Republik Indonesia Nomor 17 Tahun 2012 tentang Perkoperasian, yang 
keanggotaannya bersifat terbuka bagi seluruh golongan dan lapisan masyarakat. Oleh karena itu, LKM merupakan salah satu unit simpan pinjam koperasi bagi koperasi serba usaha, atau merupakan koperasi simpanan pinjam bagi koperasi tunggal usaha.

Bantuan pinjaman modal usaha untuk masyarakat yang disalurkan melalui LKM tersebut atau biasanya disebut Bantuan Langsung pada Masyarakat (BLM). Bantuan langsung pada masyarakat yang diberikan sebagai pinjaman modal usaha, bisa digunakan untuk modal kerja (belanja bahan-bahan/barang dagangan) atau investasi (belanja alat-alat atau sarana yang digunakan untuk usaha). Bantuan tersebut harus bergulir yang harusb dikembalikan kepada LKM karena masih banyak masyarakat lain yang membutuhkan, sementara jumlah bantuan sangat terbatas.

\section{TINJAUAN PUSTAKA}

\section{A. Perjanjian Pembiayaan pada LKM dan Pengaturannya}

1. Pengertian Perjanjian

Pengertian perjanjian diatur dalam titel

II Buku ke tiga Kitab Undang- undang Hukum Perdata (KUHPerdata), sedangkan perjanjian secara khusus diatur dalam titel XVII buku ketiga. Berdasarkan pasal 1233 menerangkan bahwa perjanjian merupakan salah satu sumber dari perikatan. Menurut subekti, perikatan adalah salah satu perhubungan hukum antara dua orang atau lebih, dimana pihak yang satu berhak menuntut sesuatu hal dari pihak lain, dan pihak yang lain berkewajiban untuk memenuhi tuntutan itu

Berdasarkan pasal 1233 dapatlah diketahui apa yang sebenamya yang dimaksud dengan perjanjian, dimana KUH Perdata menggunakan istilah persetujuan untuk menyatakan perjanjian, sebagaimana disebutkan dalam pasal 131-3 KUH Perdata yang berbunyi : " suatu persetujuan adalah suatu perbuatan dengan mana satu orang atau lebih mengikatkan dirinya terhadap satu orang atau lebih lainnya".

Pengertian perjanjian tersebut diatas mengandung beberapa unsur-unsur sebagai berikut:

1) Adanya hubungan hukum

2) Adanya para pihak

3) Adanya hubungan hukum dalam bidang harta kekayaan.

4) Adanya prestasis

Sedangkan Subekti mendefinisikan bahwa "perjanjian adalah suatu peristiwa dimana dua orang atau lebih itu saling berjanji mengikatkan diri untuk melaksanakan sesuatu hal "Muhammad Yahya Harahap menyebutkan pengertian perjanjian adalah "suatu hubungan hukurn kekayaan/harta benda antara dua orang atau lebih yang memberikan kekuatan hukum pada satu pihak untuk memperoleh prestasi dan sekaligus mewajibkan pihak yang lain untuk menunaikan prestasi.

Kemudian Ichsan Ahmad mendesfinisikan perjanjian adalah "Suatu hubungan atas dasar harta kekayaan antara dua pihak atau lebih dimana pihak yang satu berkewajiban memberikan prestasi atas mana pihak lain mempunyai hak untuk prestasi itu". Berdasarkan pengertian diatas dapat ditarik kesimpulan bahwa dalam suatu perjanjian terdapat hubungan hukum antara dua orang atau lebih yang menimbulkan hak dan kewajiban karena adanya perikatan. Maka untuk terjadinya suatu perjanjian paling kurang harus ada dua pihak, yaitu kreditur yang berhak menuntut prestasi dan debitur yang berkewajiban menunaikan prestasi. Kedua pihak mengikatkan diri untuk melaksanakan hak dan kewajiban yang telah mereka buat.

2. Perjanjian Pembiayaan Pada LKM

Definisi secara umum yang dimaksud dengan lembaga keuangan adalah "setiap perusahaan yang bergerak dibidang keuangan, menghimpun dana, menyalurkan dana atau kedua-duanya ". Artinya kegiatan yang dilakukan oleh lembaga keuangan selalu berkaitan dengan bidang keuangan, apakah kegiatannya hanya 
menghimpun dana atau hanya menyalurkan dana atau kedua-duanya menghimpun dan menyalurkan dana.

Dalam prakteknya lembaga keuangan digolongkan kedalam 2 golongan besar yaitu

a. Lembaga keuangan Bank terdiri dari :

Bank Sentral Bank Umum BPR

b. Lembaga keuangan non Bank antara lain:

Pasar Modal

Pasar Uang \& Valas

Koperasi Simpan Pinjam

Pegadaian Leasing Asuransi Anjak

Piutang

Modal Ventura

Dana Pensiun

Kartu Plastik (ATM

Di dalam Pasal 1 angka 1 Undangundang Republik Indonesia Nomor 17 Tahun 2012 tentang Perkoperasian, dinyatakan bahwa koperasi adalah "badan hukum yang didirikan oleh orang perorangan atau badan hukum koperasi, untuk dengan pemisahan kekayaan para anggotanya sebagai modal menjalankan usaha, yang memenuhi aspirasi dan kebutuhan bersama dibidang ekonomi, social, dan budaya sesuai dengan nilai dan prinsip koperasi".

Salah satu bentuk LKM yang kemudian berkembang adalah koperasi. Koperasi menurut Nindyo Pramono adalah :Suatu perkumpulan atau organisasi ekonomi yang beranggotakan orang-orang atau badanbadan yang memberikan kebebasan masuk dan keluar sebagai anggota menurut peraturan yang ada, dengan bekerja sama secara kekeluargaan menjalankan usaha dengan mempertinggi kesejahteraan jasmaniah para anggotanya.

LKM merupakan salah satu unit simpan pinjam koperasi bagi koperasi serba usaha, atau merupakan koperasi simpan pinjam bagi koperasi tunggal usaha yang kegiatannya memberikan layanan keuangan atau permodalan kepada masyarakat kecil yang tidak dilayani oleh lembaga perbankan. Salah satu usaha yang dilakukan lembaga keuangan yang menjalankan usaha dengan sistem syariah baik dan bentuk: perbankan maupun non perbankan adalah memberikan pembiayaan. Pembiayaan usaha ini dapat berupa penyediaan sejumlah uang, barang atau tagihan-tagihan yang dapat dipersamakan dengan itu berdasarkan suatu perjanjian pinjam merninjam antara LKM dan nasabah debitur.

Menurut sifat penggunaannya pembiayaan dapat dibagi menjadi dua bagian sebagai berikut:

1. Pembiayaan Produktif, yaitu pembiayaan yang ditujukan untuk memenuhi kebutuhan produksi dalam arti luas, yaitu untuk peningkatan usaha, baik usaha produksi, perdagangan maupun investasi.

2. Pembiayaan Konsumtif, yaitu pembiayaan yang digunakan untuk memenuhi kebutuhan konsumsi, yang akan habis digunakan untuk memenuhi kebutuhan.

Menurut keperluannya, pembiayaan produktif dapat dibagi menjadi dua bagian yaitu:

a. Pembiayaan Modal Kerja, yaitu pembiayaan untuk memenuhi kebutuhan seperti:

1) Peningkatan produksi, baik secara kuantitatif, yaitu jumlah hasil produksi, maupun secara kualitatif, yaitu peningkatan kualitas atau rnutu hasil produksi.

2) Untuk keperluan perdagangan atau peningkatan utility of place dari suatu barang.

b. Pembiayaan Investasi

Pembiayaan ini untuk memenuhi kebutuhan barang-barang modal (capital goods) serta fasilitas-fasilitas yang erat kaitannya dengan itu

Berdasarkan ketentuan diatas di ketahui pula bahwa istilah pembiayaan memiliki arti yang khusus yaitu pinjam meminjamkan uang. Perjanjian pinjam meminjam diatur dalam Pasal 1754 Kitab Undang-undang Hukum Perdata (KUH Perdata), yang dirumuskan sebagai berikut : "Perjanjian pinjam meminjam ialah perjanjian dengan mana pihak yang satu 
memberikan pihak yang lain suatu jumlah tertentu barang-barang yang menghabiskan karena pemakaian dengan syarat-syarat bahwa pihak yang belakangan ini akan mengembalikan sejumlah yang sama dari macam dan keadaan yang sama pula".

Pembiayaan modal usaha yang menjadikan salah satu usaha non perbankan yang menjalankan prinsip bagi hasil(syariah) adalah suatu bentuk pinjaman yang diberikan kepada masyarakat guna menambah modal usahanya dalam rangka peningkatan usaha masyarakat tersebut. Kepercayaan tidak begitu saja diberikan kepada peminjam, tetapi juga tergantung kepada unsur-unsur yaitu keadaan harta bendanya, usahanya, kemampuan dan kesanggupannya membayar kembali hutangnya yang mempunyai pengaruh sangat besar terhadap penentuan pemberian pembiayaan.

Pembiayaan yang disediakan oleh lembaga keuangan mikro dapat dimamfaatkan dan digunakan oleh debitur untuk memulai usaha baru atau membiayai usaha yang telah dijalankan sebelumnya. Lembaga keuangan mikro (LKM) merupakan lembaga non perbankan yang menggunakan sistem dan operasinya berdasarkan syariah Islam. Dengan demikian dalam pemberian pembiayaan harus menyelesaikannya dengan aturan-aturan dan norma-norma Islam.

Menurut Latifa M. Algoud dan Mevyn K. Lewis, ada 5 prinsip yang harus diterapkan dalam pemberian pembiayaan yaitu:

a. Tidak ada transaksi keuangan berbasis bunga (riba).

b. Pengenalan pajak religius atau pemberian sedekah (zakat).

c. Pelarangan produksi barang dan jasa yang bertentangan dengan sistem nilai Islam (haram).

d. Penghindaran aktivitas ekonomi yang melibatkan maysir (judi) dan gharar (ketidakpastian).

e. Penyediaan takaful (Asuransi Islam).
Dalam kegiatan pembiayaan, LKM syariah mempunyai produk-produk tersendiri yang menggunakan sebutan yang berasal dari istilah Arab. Ada beberapa produk yang menyangkut dengan penyaluran dana (pembiayaan) antara lain :

1. Pembiayaan Mudbarabab

Pembiayaan mudharabah merupakan suatu akad kerja sama pembiayaan antara LKM dengan nasabah, dimana LKM menyediakan dana $100 \%$ pembiayaan bagi usaha tertentu dari nasabah. Sedangkan nasabah mengelola usaha tersebut tanpa campur tangan LKM. LKM mempunyai hak untuk mengajukan usul dan melakukan pengawasan. Atas penyediaan dana untuk pembiayaan tersebut LKM mendapatkan imbalan atau keuntungan yang besarnya ditetapkan atas dasar persetujuan kedua belah pihak.

Meskipun pada dasamya mudharabah dapat dikategorikan dalam salah satu bentuk musyarakah, namun para cendikiawan fiqh Islam meletakkan mudharabah dalam posisi yang khusus dan memberikan landasan hukum tersendiri.

a. Al-Quran Surat Al-Muzammil : 20, yang artinya :

"... dan dari orang-orang yang berjalan di muka bumi mencari karunia Allah SWT..."

b. Al-Quran Surat Al-Jum'ah: 10 yang artinya:

"Apabila telah ditunaikan shalat maka bertebarlah kamu di muka bumi dan carilah karunia Allah SWT..."

c. Al-Quran Surat Al- Baqarah : 198 yang artinya :

"Tidak ada dosa (halangan) bagi karnu untuk mencari karunia Tuhan mu..." Munir Fuady mengatakan ada beberapa prinsip dari pembiayaan dengan Mudharabah yaitu :

1) Ada pihak penyedia dana (LKM) dan ada nasabah sebagai sebagai pihak pengelola dana.

2) Keuntungan di bagi dengan persentase. 
3) Tetapi jika menderita kerugian, maka rugi itu pun akan dipikul bersama.

d. Pembiayaan oleh LKM haruslah 100\% dari modal kerja. Sebab jika tidak $100 \%$ dibiayai, dipergunakan metode pembayaran model lain selain mudharabah.

e. LKM tidak boleh mengelola secara langsung yang dibiayainya kecuali hanya lewat pengawasan secara tidak langsung.

f. Pembiayaan mudharabah hanyalah bersifat temporer, artinya ada batas waktu pembiayaan.

Berkaitan dengan pembiayaan mudharabah ini, menurut Azis ada beberapa hal yang harus diperhatikan oleh nasabah debitur yaitu :

a. Pinjaman Al-Mudharabah (bagi hasil) ini sebaiknya diambil oleh masyarakat atau pengusaha yang sangat membutuhkan modal.

b. Peminjam hendaknya merencanakan terlebih dahulu secara matang tentang bidang usaha tempat, lokasi, pasar, jurnlah biaya yang dibutuhkan dan sebagainya.

c. Peminjam perlu menyadari bahwa uang yang akan dipinjam merupakan uang milik urnmat, oleh karena itu perlu diusahakan dan dimamfaatkan dengan benar sesuai dengan perjanjian yang telah disepakati.

d. Peminjam perlu mempelajari administrasi praktis tentang pengelolaan usaha yang sedang ditekuninya, sehingga unsur kejujuran dapat terbaca oleh LKM.

e. Peminjam dalam menyicil pinjaman dan bagi hasil, harus tepat pada waktunya sesuai dengan perjanjian yang telah ditetapkan.

2. Pembiayaan Murabahah

Pembiayaan Murabahah adalah suatu akad kerja sama pembiayaan dimana LKM membiayai pembelian barang yang diperlukan nasabah dengan sistem pembiayaan yang ditangguhkan. Pembiayaan murabahah dilakukan dengan cara LKM membeli atau memberi kuasa kepada nasabah untuk membeli barang yang diperlukan nasabah atas nama LKM. Pada saat yang bersamaaan LKM menjual barang terscbut kepada nasabah sebesar harga pokok ditambah sejumlah keuntungan untuk dibayar oleh nasabah dalam jangka waktu tertentu, sesuai dengan perjanjian antara pihak LKM dengan nasabah, Pembiayaan Murabahah ini mirip dengan Pembiayaan Modal Kerja pada Bank Konvensional, karena jangka waktu pembiayaan yang tidak lebih dari satu tahun.

A. Syarat-syarat Sahnya Perjanjian Pembiayaan

Perjanjian pembiayaan ketentuannya dalam ruang lingkup Undang-undang Perbankan dan KUH Perdata, maka mengenai syarat syarat perjanjian perlu dilihat dalam bagian umum KUH Perdata tentang perjanjian. Syarat sah perjanjian diatur dalam Buku ke III KUH Perdata Pasal 1338 yaitu menyebutkan bahwa, "Semua perjanjian yang dibuat secara sah berlaku sebagai Undang-undang bagi yang membuatnya.

Sebagaimana perjanjian pada umumnya yang ditentukan dalam Pasal 1320 KUH Perdata. Untuk sahnya perjanjian pembiayaan diperlukan adanya 4 (empat) syarat, yaitu :

1. Sepakat mereka yang mengikatkan diri;

2. Kecakapan untuk membuat suatu perikatan;

3. Suatu hal tertentu;

4. Suatu sebab yang halal.

Keempat syarat yang disebutkan diatas harus ada pada setiap perjanjian pembiayaan yang diadakan oleh para pihak. Dua syarat yang pertama dinamakan syarat subjektif karena mengenai orang-orangnya atau subjeknya yang mengadakan perjanjian, syarat terakhir dinamakan syarat-syarat objektif karena mengenai perjanjiannya sendiri atau objek perbuatan itu dilakukan.

Berikut ini syarat-syarat yang diatur dalam Pasal 1320 KUH Perdata itu akan diuraikan lebih lanjut sebagai berikut: 


\section{ad. 1 Sepakat Mereka yang Mengikatkan Diri}

Kata sepakat adalah kecocokan kehendak/kemauan antara kedua belah pihak yang mengadakan persetujuan. Menurut Mariam Darus Badrulzaman "bahwa dengan diperlukannya kata sepakat mengadakan perjanjian, maka berarti kedua belah pihak harus mempunyai kebebasan berkehendak". Kehendak atau keinginan yang disimpulkan dalam hati tidak mungkin melahirkan sepakat yang diperlukan untuk melahirkan perjanjian.

Jadi apabila terdapat kata sepakat yang diberikan karena kesilapan, paksaan dan penipuan, maka dianggap tidak pernah terjadi dan perjanjian yang telah diadakan dapat dimintakan pembatalannya Sudikno Mertukusumo, menyebutkan 3(tiga) teori tentang saat terjadinya suatu persesuaian kehendak, yaitu:

Teori pernyataan yang menyatakan bahwa persesuaian kehendak terjadi pada saat si penerima menyusun kehendaknya itu dalam bentuk surat atau telegram.

a. Teori pengiriman yang menyatakan bahwa persesuaian kehendak terjadi pada saat surat itu dikirim.

b. Teori pengetahuan dan pendengaran yang menyatakan bahwa persesuaian kehendak terjadi pada saat si penawar (yang mengadakan penawaran) mengetahui atau mendengar tentang penerimaan (aanvaarding) oleh si penerima.

Berdasarkan uraian tersebut diatas maka jelaslah bahwa kesepakatan sebagai salah satu syarat untuk sahnya perjanjian. Perjanjian pembiayaan pada LKM syariah memiliki persamaan dengan pembiayaan pada Bank syariah dalam sisi teknis penerimaan uang yaitu sama-sama berdasarkan hukum Islam yang pertanggung jawabannya hingga yaumil kiyamah nanti.

Menurut Syafi'i Antonio, bahwa setiap akad dalam perbankan maupun non perbankan syariah, baik dalam hal barang, pelaku transaksi, maupun ketentuan lainnya haruslah memenuhi ketentuan akad, seperti :

1. Rukun seperti: penjual, pembeli barang, harga, akad/ijab kabul.

2. Syarat seperti:

a. Barang dan jasa harus halal sehingga transaksi atas barang dan jasa yang haram menjadi batal demi hukum syariah.

b. Harga barang danjasa harusjelas.

c. Tempat penyerahan (delivery) harus jelas karena akan berdampak kepada biaya transportasi.

d. Barang yang di transaksikan harus sepenuhnya di dalam kepemilikan.

Namun perlu pula untuk melihat apa yang disyaratkan dalam Pasal $1449 \mathrm{KUH}$ Perdata, yang menyatakan bahwa perikatanperikatan yang dibuat dengan paksaan, kekhilafan, atau penipuan, menerbitkan suatu tuntutan untuk membatalkannya.

Didalam Islam bahwa penghormatan terhadap perjanjian hukumnya wajib, melihat pengaruhnya positif dan perannya yang besar dalam memelihara perdamaian dan melihat urgensinya dalam mengatasi kemusykilan menyelesaikan perselisihan dan menciptakan kerukunan. Syayyid Sabiq mengatakan bahwa:

"Sesungguhnya mengadakan hubungan dengan manusia dengan baik, menepati janji, bersikap benar terhadap mereka adalah pertanda seumpamanya kepribadian dan harga diri serta suatu lambang keadilan. Orang yang seperti ini wajib dijadikan saudara dan sahabat, Allah SWT memerintahkan agar memenuhi janji, baik terhadap Allah maupun terhadap manusia. Sesuai dengan firman Allah yang tertulis dalam Q.S. 5 ayat I yang artinya " Hai orang-orang yang beriman, penuhilah akad perjanjianmu.

Dengan demikian, apabila seseorang dalam mengikat suatu perjanjian tidak memberikan kesepakatan secara bebas, karena ada paksaan, khilaf, penipuan, maka pihak tersebut dapat memnta pembatalan kepada hakim dengan cara mengajukan gugatan kepengadilan. 


\section{ad. 2 Kecakapan untuk Membuat Suatu Perikatan}

Dalam melaksanakan suatu perjanjian di haruskan orang yang cakap bertindak dalam Ialu lintas hukum, karena dalam perjanjian itu seseorang terikat untuk melaksanakan suatu prestasi dan mereka harus dapat mempertanggung jawabkannya. Hal itu sesuai dengan ketentuan Pasal 1329 KUH Perdata yang menyatakan "bahwa setiap orang cakap untuk mengadakan suatu persetujuan, kecuali orang yang oleh Undang-undang dinyatakan tidak cakap".

Pada umumnya orang itu dikatakan cakap melakukan perbuatan hukum, apabila ia sudah dewasa artinya sudah mencapai umur 21 tahun atau sudah kawin walaupun belum berumur 21 tahun. Dalam pasal 1330 KUH Perdata disebut sebagai orang-orang yang tidak cakap untuk membuat suatu perjanjian :

1. Orang-orang yang belum dewasa

2. Mereka yang ditaruh dibawah pengampuan

3. Orang perempuan dalam hal-hal yang telah ditetapkan oleh orang Undangundang telah melarang membuat perjanjian tertentu.

Menurut M.Yahya Harahap, subjek yang dianggap cakap membuat persetujuan ialah orang yang mampu melakukan tindakan hukum. Umurnnya mereka yang mampu melakukan tindakan hukum ialah orang dewasa clan waras akal budinya.

\section{ad. 3 Suatu Hal Tertentu}

Menurut pasal 1320 KUH Perdata syarat ke 3 (tiga) untuk sahnya suatu perjanjian adalah tentang suatu hal tertentu. Artinya apa yang diperjanjikan hak-hak dan kewajiban kedua belah pihakjika timbul suatu perselisihan.

Barang yang dimaksudkan dalam perjanjian paling sedikit harus ditentukan jenisnya, Bahwa barang yang sudah ada ditangannya si berhutang pada waktu perjanjian dibuat, tidak diharuskan oleh Undang-undang. Juga jumlahnya tidak perlu disebutkan, asal saja kemudian dapat dihitung atau ditetapkan (Pasal 1333 KUH Perdata).

Akibat syarat bahwa prestasi itu harus tertentu atau dapat ditentukan, gunanya ialah untuk menetapkan hak dan kewajiban kedua belah pihak, jika timbul perselisihan dalam pelaksanaan perjanjian. Jika prestasi itu kabur, sehingga perjanjian itu tidak dapat dilaksanakan, maka perjanjian itu dianggap batal demi hukum.

\section{ad.4 Suatu Sebab yang Halal}

Dalam KUH Perdata sebagaimana dimuat dalam Pasal 1337, disebutkan bahwa "pengertian causa atau sebab yang halal tersebut harus dilihat dari sudut Undangundang, ketertiban umum dan kesusilaan, maka tidak diperkenankan atau persetujuan itu batal demi hukum". Sebaiknya, apabila dalam suatu perjanjian tidak dinyatakan suatu sebab, tetapi dalam perjanjian tersebut terdapat suatu sebab yang halal, maka perjanjian itu sah. Dari ke empat syarat tersebut digolongkan 2 katagori, yaitu:

a. Mengenai subjek perjanjian ialah :

1) Orang yang membuat perjanjian harus cakap atau mampu melakukan perbuatan hokum.

2) Sepakat (konsensus) yang menjadi dasar perjanjian yang harus dicapai atau kebebasan menentukan kehendaknya (tidak ada paksaan, kekhilafan/atau penipuan)

b. Mengenai objek perjanjian ditentukan, bahwa :

1) Apa yang diperjanjiakan oleh masing-masing harus jelas untuk menetapkan kewajiban masingrnasing pihak.

2) Apa yang diperjanjikan oleh masingmasing tidak bertentangan engan Undang-undang, ketertiban umum, atau kesusilaan.

Dalam hubungan dengan perjanjian pembiayaanm syarat-syarat tersebut juga berlaku. Jadi apabila di dalam suatu perjanjian pembiayaan tidak dipenuhi keempat syarat-syarat yang diatur dalam pasal $1320 \mathrm{KUH}$ Perdata, rnaka perjanjian 
pernbiayaan itu dapat dimintakan pernbatalannya oleh salah satu pihak yang rnernuat perjanjian pembiayaan.

Dalam setiap perjanjian pembiayaan, bahwa si penerima pembiayaan datang sendiri ke LKM atas kemauannya sendiri, dan penerima pembiayaan haruslah sudah dewasa ataupun tidak berada di bawah pengampuan orang lain. Sebagai objek dari perjanjian pembiayaan itu adalah sejumlah uang tertentu, sehingga pihak LKM sebagai pihak kreditur haruslah menyerahkan uang tertentu kepada pihak penerima pembiayaan (debitur).

LKM sebagai pihak kreditur berhak menuntut pengembalian uang tersebut dari pihak debitur. Sedangkan debitur menuntut agar sejwnlah uang yang telah diperjanjikan dengan pihak LKM diserahkan kepadanya dan berkewajiban mengembalikan pinjamannya setelah jangka waktu yang telah ditentukan.

Berdasarkan syarat sah perjanjian yang terdapat dalam pasal $1320 \mathrm{KUH}$ perdata, maka dalam perjanjian pembiayaan juga terdapat beberapa syarat yang harus dipenuhi oleh nasabah dalam perjanjian pemberian pembiayaan pada LKM yaitu:

1. Islam

Bahwa setiap nasabah yang diberi pembiayaan oleh LKM haruslah beragama Islam. Ini merupakan syarat mutlak dan tidak dapat ditawar-tawar lagi karena menyangkut dengan ijab qabul yang harus di ikrarkan oleh kedua belah pihak dengan menyebut nama Allah SWT.

2. Jangka wak:tu pembiayaan

Dalam pemberian pembiayan LKM menentukan lamanya pembiayaan. Lamanya pembiayaan yang diberikan oleh LKM tergantung kesepakatan antara debitur dengan LKM. Penentuan jangka waktu pembiayaan ini sangat diperlukan karena selama jangka waktu yang diperjanjikan tersebut kedua belah pihak mempunyai hubungan hukum yang dibebani oleh hak clan kewajiban yang harus dipikul oleh para pihak, bukan berarti bila terjadi wanprestasi hubungan hukum tersebut putus apabila perjanjian berakhir sesuai dengan apa yang diperjanjikan.

3. Imbalan bagi hasil

Besarnya imbalan bagi hasil ditentukan melalui kesepakatan tawar menawar antara pihak LKM dengan debitur. Besamya persentase bagi hasil tersebut sangat ditentukan oleh lapangan usaha nasabah dan penilaian LKM.

4. Sanggup memenuhi semua ketentuan yang telah berlaku

Semua ketentuan yang telah disepakati haruslah dipatuhi dan dilaksanakan secara baik dan benar. Ketentuan tersebut telah dituangkan didalam perjanjian pembiayaan. Apabila ada penyimpangan-penyimpangan yang dilakukan oleh debitur, maka LKM secara sepihak dapat membatalkan perjanjian pembiayaan tersebut setelah melalui teguran dan peringatan.

\section{B. Hak dan Kewajiban Para Pihak dalam Perjanjian Pembiayaan}

Dalam perjanjian pembiayaan sama halnya dalam perjanjian pada umumnya yang ditentukan secara tegas tentang saat terjadinya perjanjian, namun jika dilihat pada pasal $1320 \mathrm{KUH}$ Perdata maka terjadinya perjanjian pembiayaan adalah pada saat terjadinya persesuaian pemyataan kehendak para pihak yaitu antara debitur dengan LKM. Terjadinya perjanjian pembiayaan adalah pada saat ditandatangani perjanjian pembiayaan oleh para pihak. Dengan terjadinya perjanjian pembiayaan maka timbullah hak dan kewajiban para pihak sebagaimana yang telah diperjanjikan.

Dalam menguraikan hak dan kewajiban para pihak, maka untuk lebih jelas akan diuraikan terlebih dahulu tentang para pihak yang tersangkut dalam perjanjian pembiayaan pada LKM.

1. Para pihak dalam perjanjian pembiayaan Pada dasamya dalam perjanjian pembiayaan akan melibatkan dua pihak yaitu: 
a. Pihak pemberi pembiayaan (kreditur)

Sehubungan dengan para pihak, pemberi pembiayaan disini adalah LKM. Dalam prakteknya sehari-hari biasanya LKM dalam memberikan pembiayaan telah menyiapkan suatu konsep yang memuat tentang syarat dan isi perjanjian pembiayaan yang akan mereka lakukan.

Jika syarat-syarat yang telah diajukan tersebut telah terpenuhi oleh calon penerima pembiayaan yang telah disiapkan sebelumnya oleh LKM yang sebelumnya tidak pemah di musyawarahkan terlebih dahulu dengan pihak penerima perjanjian pembiayaan termasuk sebagai suatu perjanjian standar atau perjanjian baku yaitu perjanjian yang isinya dibakukan dan dituangkan dalam bentuk formulir.

b. Pihak penerima pembiayaan (debitur)

Di dalam Bab XIII Buku III KUH Perdata tidak dijelaskan tentang penerima pinjaman, siapa saja dapat menjadi penerima pinjaman. Demikian juga dalam Undangundang Meminjamkan Uang 1938 (S. 1939 No. 523), secara tegas tidak disebutkan tentang penerima pembiayaan. Namun secara umum dapat disebutkan bahwa penerima pembiayaan pada LKM adalah Perorangan (Individu) dan kelompok.

2. Hak dan kewajiban para pihak

Perjanjian pembiayaan pada LKM akan melibatkan dua pihak yaitu pemberi pembiayaan dan penerima pembiayaan atau istilah lain kreditur clan debitur. Untuk mengetahui hak clan kewajiban para pihak dalam perjanjian pembiayaan pada LKM, dapat dilihat dalam isi perjanjian yang telah mereka sepakati.

a. Hak dan kewajiban kreditur

LKM selaku pemberi pembiayaan (kreditur) mempunyai kewajiban- kewajiban yang harus dipenuhi untuk penerima pembiayaan (debitur) yaitu menyediakan dana untuk dipergunakan sesuai dengan rencana penggunaan pembiayaan oleh debitur. Selain kewajiban tersebut di atas, LKM berkewajiban juga untuk mengawasi dan memberikan bimbingan clan petunjuk-petunjuk kepada kreditur sehubungan dengan pembiayaan yang diberikannya.

Disamping kewajiban-kewajiban sebagaimana tersebut di atas, dengan adanya perjanjian pembiayaan clan penyerahan uang, serta barang kepada debitur, maka LKM sebagai kreditur juga memperoleh hak-hak sebagai berikut:

1. Menerima provisi clan pembagian keuntungan atas pinjaman yang telah ditetapkan sesuai dengan ketentuan yang telah dicantumkan dalam perjanjian pembiayaan.

2. Mencabut kembali uang peminjaman yang telah diterima oleh debitur apabila debitur baik sengaja atau tidak telah melanggar ketentuan- ketentuan yang telah disepakati bersama.

3. Menagih/menarik modal dan keuntungan tersebut dari debitur apabila telahjatuh tempo sesuai menurut surat perjanjian.

4. Setiap waktu yang diperlukan LKM berhak meminta keterangan tentang pembukuan debitur terhadap penggunaan pinjaman.

5. LKM secara sepihak dapat mengakhiri pembiayaan dan mencabut/menyita barang-barang jaminan debitur untuk menutupi pinjaman apabila:

a. Usaha pembiayaan dinyatakan pailit atau mendapatkan penundaan pembayaran baik yang bersifat sementara maupun tetap.

b. Jika terhadap kekayaan peminjam diletakkan sita jaminan oleh. Pengadilan Negeri setempat atas suatu perkara dengan pihak ketiga

c. Jika peminjam tidak melaksanakan kewajibannya sebagaimana telah disepakati bersama (terjadi penunggakan pembiayaan).

d. Jika perninjam secara langsung atau tidak langsung ikut terlibat tindak pidana atau gerakan anti pemerintah yang diancam pidana penjara, untuk itu LKM tidak perlu menunggu keputusan pengadilan.

e. Jika peminjam meninggal dunia. 
b. Hak dan kewajiban debitur

Sebagaimana yangtelah dikemukakan, yaitu mengenai hak dan kewajiban pemberi pembiayaan yang timbul karena adanya perjanjian pembiayaan adalah kebalikan dari uraian yang telah diutarakan diatas. Adapun kewajiban dari debitur adalah:

1) Wajib membayar biaya materai.

2) Wajib membayar provinsi (biaya administrasi) atas pijaman yang diberikan.

3) Wajib mengembalikan pinjaman dalamjumlah yang sama (jumlah pokok) beserta keuntungan menurut yang telah diperjanjikan.

4) Wajib memberikan bukti-bukti milik debitur sebagai pmjaman atas pinjaman yang telah diberikan.

5) Mengikuti petunjuk-petunjuk dan bimbingan teknis yang diberikan oleh petugas yang berwenang.

6) Melaporkan segala sesuatu yang terjadi terhadap usaha yang dijalankan dalam waktu yang secepat-cepatnya, apabila terjadi hal-hal diluar dugaan dari perjanjian ini.

7) Memberikan laporan sebelumnya sehubungan dengan adanya perubahan alamat, tidak sekali-kali memindah tangankan kepada pihak lain sebelum mendapat persetujuan dari kreditur (LKM).

8) Memamfaatkan modal usaha dari LKM untuk menjalankan usahanya

Sebagaimana diketahui bahwa kewajiban-kewajiban tersebut timbul karena adanya perjanjian pembiayaan. Sedangk.an hak-hak debitur yang lahir dari perjanjian pembiayaan adalah:

1) Menerima uang berupa pinjaman sebesar jumlah yang tercantum dalam perjanjian pembiayaan.

2) Berhak menerima bimbingan dan petunjuk-petunjuk dari LKM sehubungan dengan kegiatan peningkatan usahanya.

3) Menerima kuitansi yang merupakan bukti atas pengembalian dan penyetoran serta pembebanan-pembebanan lainnya yang dilaksanakan oleh LKM.

4) Menerima kembali bukti-bukti hak milik yang dijadikan jaminan apabila uang yang telah dipinjamkan telah dilunasi.

C. Wanprestasi serta Akibat Hukumnya

Di dalam setiap perjanjian yang dibuat oleh para pihak pada prinsipnya para pihak tersebut harus melakukan kewajiban secara timbal balik. Dalam perjanjian pernbiayaan, pihak yang memberikan pembiayaan (kreditur) berkewajiban menyerahkan uang kepada pihak debitur untuk: dipergunakan sepenuhnya dalam jangka waktu tertentu. Sebaliknya pihak debitur berkewajiban rnengembalikan pinjamannya dalam jangka waktu yang telah diperjanjikan, berikut dengan keuntungan yang telah disepakati bersama berdasarkan prinsip bagi hasil. Jika debitur tidak memenuhi perjanjian sebagaimana mestinya dan kesemuanya itu dapat dipersalahkan kepadanya maka dikatakan bahwa debitur tersebut wanprestasi.

Perkataan wanprestasi berasal dari bahasa Belanda, yang berarti prestasi buruk. Menurut Subekti, wanprestasi adalah "apabila siberutang (debitur) tidak melakukan apa yang diperjanjikan, maka ia dikatakan telah wanprestasi". Ia alpa atau "lalai" atau ingkar janji. Atau apabila ia melanggar perjanjian, bila ia melakukan atau berbuat sesuatu yang tidak boleh dilakukannya.

Adapun pengertian wanprestasi secara umum adalah pelaksanaan yang tidak tepat pada waktunya atau dilakukan tidak menurut selayaknya. Seperti yang telah ditetapkan dalam perjanjian tidak dipenuhinya kewajiban debitur disebabkan oleh dua kemungkinan alasan yaitu:

1. Karena kesalahan debitur, baik dengan sengaja tidak dipenuhi kewajiban maupun karena kelalaian.

2. Karena keadaan memaksa (overmacht), force majeure. Jadi diluar kemampuan debitur, debitur tidak bersalah. 
Wanprestasi seorang debitur menurut Subekti dapat berupa 4 (empat) macam perbuatan yaitu:

1. Tidak melakukan apa yang disanggupi akan dilakukan.

2. Melaksanakan apa yang diperjanjikan, tetapi tidak sebagaimana mestinya.

3. Melakukan apa yang diperjanjikan tetapi terlambat.

4. Melakukan sesuatu menurut perjanjian tidak boleh dilakukan.

\section{UPAYA PENYELESAIAN}

\section{TUNGGAKAN DEBITUR}

\section{A. Proses Pemberian Pembiayaan pada \\ LKM Syariah}

Sebagaimana diketahui bahwa bantuan langsung yang disalurkan oleh LKM Syariah adalah dana bantuan yang berasal dari Pemerintah, dana untuk dapat dimamfaatkan bagi kepentingan dan kesejahteraan masyarakat khususnya korban bencana tsunami dan konflik. Dana yang disalurkan pada masyarakat adalah dalam bentuk pinjaman yang harus dikembalikan dengan cicilan/angsuran dalam jangka waktu tertentu dan bersifar bergulir bagi seluruh lapisan masyarakat.

Untuk memperoleh pembiayaan tersebut harus melalui proses tahapan yang berlaku secara umum antara lain adanya permohonan pembiayaan, pengumpulan data, analisa pembiayaan, persetujuan, pengumpulan data tambahan, pengikatan, pencairan dan monitoring.

Dalam suatu proses pembiayaan, prosedur pemberian pembiayaan pada LKM Syariah adalah sebagai berikut:

1. Pengajuan permohonan pembiayaan

Data yang dikumpulkan oleh bagian lapangan diserahkan pada bagian keuangan dan -pernbiayaan untuk dianalisa apakah terhadap calon nasabah perninjarn dapat diberikan pernbiayaan dan juga untuk rnenentukan besamya pernbiayaan yang dapat diberikan. Selain itu, juga rnenentukan besarnya taksiran atas barang-barang yang dijadikan jaminan bila calon nasabah perninjam yang bersangkutan di syaratkan.
Dalam analisa ini juga dianalisis rnengenai kelayakan usaha dan juga apakah jenis usaha yang akan dikernbangkan itu dibenarkan oleh Islam (halal) atau tidak.

2. Pengarnbilan keputusan

Keputusan diterirna atau tidaknya permohonan pernbiayaan ditentukan oleh pimpinan berdasarkan rekomendasi bagian keuangan dan pembiayaan. Apabila permohonan pernbiayaan diterirna, pihak LKM segera mernberitahukan kepada calon nasabah perninjarn. Pemberitahuan tersebut dilakukan oleh bagian lapangan dengan menghubungi calon nasabah peminjarn agar datang ke kantor untuk realisasi dan penandatanganan Surat Perjanjian Pembiayaan. Apabila permohonannya ditolak pihak LKM juga rnemberitahukan kepada calon nasabah perminjam secara tertulis. Seluruh proses diatas, mulai dari pengajuan pennohonan sampai pemberitahuan keputusan diterirna atau tidaknya permoohonan pernbiayaan harus dilakukan dalarn waktu yang cepat, biasanya seminggu mengingat jumlah peminjaman yang relatif banyak.

3. Realisasi pembiayaan.

Apabila permohonan pembiayaan diterima, maka bagian keuangan dan pembiayaan akan membuat surat perjanjian pembiayaan untuk ditanda tangani oleh pimpinan LKM sebagai pemberi pembiayaan dan nasabah debitur sebagai penerima pembiayaan serta staf LKM sebagai saksi. Selain itu juga dibuat daftar angsuran yang menjadi pegangan kedua belah pihak dalam pengembalian pembiayaan.

Berdasarkan penelaahan terhadap perjanjian pembiayaan yang dibuat antara pihak LKM Syariah dengan nasabah debitur diketahui bahwa dalam perjanjian pembiayaan tersebut dimuat antara lain:

1. Judul pembiayaan, yang dalam suatu perjanjian pembiayaan mutlak adanya sehingga setiap orang yang berkepentingan akan melihat dengan 
mudah dan mengetahui bahwa akta yang mereka lihat adalah suatu akta perjanjian pembiayaan.

2. Komparisi, yaitu bagian dari suatu akta yang membuat keterangan tentang orang/pihak yang bertindak mengadakan perbuatan hukum. Penuangannya berupa

a. Uraian rinci tentang identitas, meliputi nama, pekerjaan, alamat, para pihak.

b. Dasar hukum yang memberi kewenangan yuridis untuk bertindak dari para pihak.

c. Kedudukan para pihak.

3. Isi perjanjian, yaitu bagian dari perjanjian pembagian yang didalamnya dimuat halhal yang diperjanjikan para pihak.

4. Penutup, yaitu bagian atau tempat dimuatnya hal-hal :
a. Pilihan domosili hukum para pihak
b. Tempat dan tanggal perjanjian ditandatangani
c. Tanggal mulai berlakunya perjanjian.

5. Saksi-saksi, yaitu pihak yang menyaksikan pelaksanaan perjanjian. Saksi-saksi hanya terdapat dalam perjanjiann pembiayaan, yang membedakan dengan perjanjian kredit pada bank konvensional. Selanjutnya pada waktu penandatanganan akad perjanjian,setiap akad perjanjian tersebut terdiri dari pasal-pasal, untuk lebih jelasnya keterangan isi pasal- pasal dalam akad perjanjian pembiayaan tersebut dapat dilihat pada Iampiran mengenai perjanjian pembiayaan.

Dalam perjanjian ini dilakukan juga pemyataan lisan atau ijab kabul antara kedua belah pihak sebagai salah satu rukun muamalah, setelah melalui proses yang dimaksud barulah peminjam dapat melakukan penarikan pembiayaan.

Berdasarkan hasil penelitian pada LKM Syariah ditemukan bahwa yang termuat dalam akad perjanjian antara LKM dengan debitur tidak dilaksanakan sebagaimana mestinya. Menurut pasal 1338 KUH Perdata ayat (1) yang berbunyi "Semua perjanjian yang dibuat secara sah berlaku sebagai Undang-undang bagi mereka yang membuatnya". Dalam praktek pihak LKM Syariah tidak menerapkan semua yang ada dalam perjanjian salah satu diantara mengenai jaminan saat mengambil pembiayaan.

Didalam pasal 6 akad perjanjian pembiayaan mudharabah, dan pasal 3 perjanjian murabahah disebutkan bahwa debitur diwajibkan untuk menjamin pelunasan hutang, narnun pihak LKM tidak menuntut adanya jaminan pada setiap debitur yang mengambil pembiayaan.

Kemudian didalam pasal 7 ayat (1) akad perjanjian mudharabah disebutkan "jika pihak kedua menggunakan pembiayaan yang telah diberikan oleh pihak pertama untuk digunakan diluar keperluan dan kepentingan pembiayaan atas kesepakatan bagi hasil ini, maka seluruh pembiayaan tersebut akan menjadi jatuh tempo dan menjadi kewajiban yang harus segera dibayarkan kepada pihak pertama secara seketika".

Namun dalam praktek terhadap debitur yang melakukan hal-hal yang dimaksud dalarn pasal tersebut pihak LKM tidak mengambil tindakan apapun, pihak LKM sangat sulit untuk mengambil tindakan sebagaimana yang termuat dalam akad perjanjian karena tidak mendapat respon dari debitur, untuk melunasi angsuran pembiayaan sangat sulit dipenuhi apalagi untuk rnemenuhi resiko karena pelanggaran perjanjian. Pihak LKM selalu berupaya melakukan musyawarah dan membicarakan hal-hal mengenai perjanjian untuk mencapai suatu pemecahan masalah sehingga semua dapat diatasi dengan baik.

Selanjutnya setelah menerirna pembiayaan, maka kepada debitur diwajibkan untuk mengernbalikan pembiayaan sesuai dengan jadwal yang telah disepakati. Proses pengembalian pembiayaan pada LKM Syariah dilakukan dengan dua cara, yaitu:

1. Debitur sebagai nasabah peminjam rnengernbalikan pernbiayaan secara 
cicilan dalam jumlah dan jangka waktu yang telah ditetapkan secara bersama oleh LKM Syariah .

2. Pihak LKM Syariah melalui petugas lapangan menagih setoran angsuran pembiayaan.

Angsuran pertama dibayar pada saat penandatanganan perjanjian dan pencairan pembiayaan dan terhitung sebulan seterusnya hingga jatuh tempo.

\section{B. Faktor Penyebab Debitur tidak Melaksanakan Kewajiban Pembayaran Angsuran}

Dalam pemberian pembiayaan kepada debitur, LKM Syariah walaupun telah menempuh berbagai cara yang memudahkan debitur dalam pengembalian pembiayaan guna menghindari tunggakan, namun tetap menghadapi berbagai permasalahan. Permasalahan tersebut timbul setelah pembiayaan diberikan dan debitur yang bersangkutan enggan mengembalikan pinjamannya. Debitur tidak mau memenuhi prestasinya dalam jumlah dan waktu yang telah diperjanjikan, hal ini merupakan resiko yang harus ditanggung oleh LKM Syariah .

Dari penjelasan diatas, maka debitur yang mengambil pembiayaan pada LKM Syariah telah melakukan wanprestasi atau tidak memenuhi prestasi seperti yang diperjanjikan. Adapun bentuk wanprestasi yang dilakukan nasabah debitur tersebut berupa :

1. Terlambat melakukan pelunasan pembiayaan.

Terlambat melakukan pelunasan modal usaha artinya debitur telah melaksanakan prestasinya yaitu mengembalikan pembiayaan kepada LKM Syariah tetapi tidak tepat pada waktunya atau telah lewat waktu yang ditentukan dalam perjanjian.

2. Tidak membayar secara keseluruhan (tidak lunas)

Membayar tetapi tidak secara keseluruhan (tidak lunas) adalah bahwa debitur dalam perjanjian pembiayaan memang melaksanakan pembayaran pembiayaan tetapi terjadi tunggakantunggakan baik untuk tunggakan dalam pembayaran pinjaman pokok maupun imbalan bagi hasil yang telah ditetapkan.

3. Tidak membayar sama sekali.

Tidak membayar sama sekali adalah dimana debitur dalam pembayaran modal usaha hanya membayar imbalan bagi hasil tetapi untuk pinjaman pokok tidak pemah dilakukan pembayaran sehingga terjadi tunggakan.

Berdasarkan uraian diatas jelaslah bahwa dalam praktek perjanjian pembiayaan modal usaha pada LKM Syariah terjadi wanprestasi terdiri atas tiga bentuk, yaitu, terlambat melakukan pelunasan pembiayaan, tidak membayar secara keseluruhan (tidak lunas),dan tidak membayar sama sekali.

Dalam akad perjanjian ini disebutkan bahwa kewajiban pihak LKM adalah memberikan pengawasan dan bimbingan atas aktivitas usaha pihak. debitur selama perjanjian berlangsung.Tetapi pada kenyataannya pihak LKM kurang melakukan pengawasan, Pihak LKM kurang melakukan pengawasan karena terbatasnya staf bagian lapangan. Jadi faktor penyebab nasabah debitur melakukan wanprestasi atau tidak melaksanakan kewajiban pembayaran angsuran adalah:

a. Kurangnya kesadaran hukum dari nasabah untuk melunasi pembiayaaan

b. Kondisi ekonomi yang tidak stabil

c. Penggunaan pembiayaan tidak semestinya

d. Gagal usaha

e. Kurangnya pengawasan.

Mengenai hal ini untuk lebih jelasnya dapat dilihat pada uraian berikut :

1. Kurangnya kesadaran hukum dari nasabah untuk melunasi pinjaman

Dengan adanya perjanjian pinjam meminjam modal usaha antara LKM dengan debitur yang telah disepakati dengan ditandatangani oleh kedua belah pihak, maka secara yuridis berlakulah ketentuan mengenai hak dan kewajiban yang harus dipenuhi.Walaupun perjanjian yang dibuat 
telah mengikat para pihak sedemikian rupa, namun masih ada pihak yang tidak melaksanakannya dengan sempurna. Hal ini disebabkan rendahnya kesadaran hukum debitur tentang hak dan kewajibannya.

2 . Kondisi ekonomi yang tidak stabil

Timbulnya wanprestasi dalam perjanjian pembiayaan pada LKM Syariah tidak sepenuhnya disebabkan oleh nasabah yang tidak melaksanakan perjanjian. penyebab melakukan tunggakan dalam mengembalikan modal usaha sehingga dikatakan wanprestasi adalah karena tidak stabilnya harga yang menyebabkan penjualan menjadi tidak lancar.

Pengembalian modal usaha adalah karena harga pasaran yang tidak stabil sehingga dalam memasarkan produknya menjadi terganggu dalam mengembangkan usaha rumah tangga Adanya harga yang tidak stabil menyebabkan usahanya menjadi kurang lancar karena daya beli masyarakat menjadi kecil apabila harga dipasaran meningkat disamping ia harus menyediakan modal yang lebihjika harga bahan bakujuga naik.

Dengan demikian jelaslah bahwa tidak stabilnya harga dan pergantian bentuk usaha akan mempengaruhi kelancaran usaha dari masyarakat di daerah tersebut.

3. Penggunaan pembiayaan tidak semestinya

Dalam pemberian modal usaha oleh LKM Syariah kepada debitur tujuannya agar debitur dapat lebih mengembangkan usahanya sehingga tingkat pendapatan dan ekonomi menjadi lebih baik. Namun pada kenyataannya setelah nasabah debitur menerima pembiayaan, mereka menggunakan dana modal usaha tidak sebagaimana mestinya. Tunggakan yang dilakukan oleh nasabah debitur dalam pengembalian pembiayaan modal kerja kepada pihak LKM Syariah juga disebabkan karena adanya penyalahgunaan modal usaha untuk kepentingan yang bersifat konsurntif. Dengan demikian modal usaha yang diharapkan dapat membantu pengembangan usaha bagi debitur habis begitu saja dan pada saat jatuh tempo mengembalikan modal usaha pada LKM tidak dapat mereka laksanakan.

\section{Kurangnya pengawasan}

Seperti yang diketahui bahwa pengawasan oleh pihak LKM setelah pembiayaan diberikan merupakan faktor yang sangat penting. Namun, kurangnya pengawas lapangan menyebabkan pihak LKM tidak dapat melakukan pengawasan secara maksimal dan rutin. Dengan pengawasan yang demikian, menyebabkan debitur melakukan penyalahgunaan pembiayaan.

Faktor pengawasan merupakan faktor penting setelah pembiayaan diberikan kepada debitur guna mendorong kemsbalinya pembiayaan yang disalurkan. Tanpa adanya pengawasan menyebabkan debitur menyalahgunakan pembiayaan yang diterimanya, Dengan pengawasan, pihak LKM juga akan dapat melihat dan memberikan bimbingan terhadap nasabah debitur bila mengalami kesulitan terhadap pengembangan usahanya.

Bahwa kurangnya pengawasan dari pihak LKM juga merupakan pendorong terjadinya wanprestasi akibat penyalahgunaan pembiayaan yang diberikan. Hal ini menurutnya karena keterbatasan tenaga lapangan yang biasanya melakukan kunjungan ke debitur.

Berdasarkan uraian yang dipaparkan di atas jelaslah faktor penyebab terjadinya wanprestasi dalam praktek pemberian pembiayaan modal usaha pada LKM Syariah adalah kurangnya kesadaran dari debitur untuk melunasi pembiayaan, tidak stabilnya harga dan pergantian bentuk usaha, penggunaan pembiayaan tidak semestinya, dan kurangnya pengawasan oleh pihak LKM. 


\section{Upaya Penyelesaian yang dilakukan Kreditur terhadap Debitur yang Tidak Melaksanakan Kewajiban Pembayaran Angsuran dan Kendala yang Dihadapi}

Adanya pembiayaan yang bermasalah, baik yang besar maupun yang relatif kecil dapat mempengaruhi tingkat kesehatan dan bonafitas suatu lembaga keuangan termasuk Lembaga Keuangan Mikro. LKM Syariah Ade Beurata sebagai lembaga keuangan yang menyimpan dananya, harus berusaha agar para nasabah dapat merasa aman dan mendapat keuntungan yang halal.

Dalam mengatasi hal tersebut LKM Syariah melakukan usaha-usaha pembinaan bagi debitur khususnya yang menerima pembiayaan modal usaha, yang dilakukan oleh staf bagian lapangan dan pembiayaan. Hal ini dimaksudkan agar pembiayaan yang diberikan dapat digunakan sebaik-baiknya sesuai peruntukannya dalarn rangka mengembangkan usahanya.

Ada 4 kriteria nasabah debitur yang melakukan penunggakan pembayaran angsuran pembiayaan (wanprestasi) pada LKM Syariah :

a. DPK (dalam perhatian khusus), nasabah menunggak pembayaran 1 sampai 3 bulan.

b. Kurang lancar, nasabah menunggak pembayaran 3 sampai 6 bulan.

c. Diragukan, nasabah menunggak pembayaran 6 sampai 9 bulan.

d. Macet, nasabah menunggak pembayaran lebih dari 9 bulan.

Namun, apabila kemacetan atau tunggakan angsuran pembiayaan disebabkan oleh faktor intern, yaitu karena kesalahan debitur seperti terlambat dalam membayar cicilan pembiayaannya, maka berarti debitur telah melakukan wanprestasi. Langkahlangkah yang ditempuh LKM Syariah pada jalur musyawarah ini adalah sebagai berikut :

a. Pemberitahuan

Dalam hal ini telah terjadi penunggakan pembiayaan oleh debitur selama beberapa bulan, maka LKM mengirimkan surat pemberitahuan kepada debitur yang berisikan jurnlah tagihan pembiayaan yang belurn disetor (tagihan pokok pembiayaan ditambah nisbah LKM). Pemberitahuan ini dimaksudkan agar debitur dapat menyelesaikan pembiayaan tersebut sebagaimana mestinya.

b. Peringatan

Dalam hal terjadi kemacetan pembiayaan atau pembiayaan telah jatuh tempo maka LKM mengirimkan Surat Peringatan kepada debitur melalui petugas lapangan dimana LKM meminta kepada debitur agar segera menyelesaikan pembiayaanya. Di dalam surat tersebut disebutkan tagihan pokok dan nisbah bagi hasil. Teguran terhadap debitur yang menunggak tersebut dilakukan sampai pada teguran ketiga.

c. Memanggil debitur ke LKM dan melakukan wawncara untuk melihat permasalahan yang dialami nasabah.

Faktor-faktor yang menyebabkan debitur tidak memenuhi kewajibannya dan untuk dicarikan jalan keluar mengatasi pembiayaan yang bermasalah tersebut. Pemanggilan ini juga telah dilakukan kepada semua nasabah yang tidak dapat melaksanakan kewajiban dalam pengembalian cicilan pembiayaan.

d. Mendatangi tempat tinggal penerima pembiayaan.

Usaha lain yang dilakukan LKM Syariah adalah mendatangi tempat tinggal debitur pembiayaan untuk melakukan penagihan. Apabila dari pantauan pihak LKM adanya hal-hal yang dilakukan pihak debitur yang tida sesuai dengan perjanjian, biasanya pihak LKM hanya sekedar memberi teguran saja, padahal menurut KUH Perdata debitur tersebut telah melanggar perjanjian harus menanggung resiko.

Namun sejauh ini semua usaha yang dilakukan LKM masih jauh dari hasil sebagaimana yang diharapkan, debitur masih saja tidak mengindahkan upaya-upaya yang telah dilakukan pihak LKM, sehingga pada akhimya pihak LKM harus mengambil kebijakan sendiri dengan cara mengirim surat 
kepada debitur sebagai teguran terakhir untuk melakukan pemenuhan perjanjian dan mengganti nisbah bagi basil yang akan diperoleh LKM seandainya perjanjian dipenuhi. Penerapan denda terhadap debitur yang melakukan wanprestasi selama.

\section{PENUTUP}

\section{A. Kesimpulan}

1. Proses mendapatkan pembiayaan modal usaha pada LKM Syariah diawali dengan adanya permohonan pembiayaan, pengumpulan data, analisa pembiayaan, persetujuan, pengumpulan data tambahan, pengikatan, pencairan dan monitoring.

2. Faktor yang menyebabkan debitur rnelakukan pelanggaran jatuh tempo pembiayaan adalah kurangnya kesadaran hukum debitur untuk mengembalikan pembiayaan, kondisi ekonomi yang tidak stabil, penggunaan pembiayaan tidak sebagaimana mestinya, gagal usaha dan kurangnya pengawasan dari pihak LKM.

3. Upaya penyelesaian yang dilakukan LKM Syariah untuk penyelesaian tunggakan debitur lebih menekankan kepada musyawarah dan damai diluar pengadilan., upaya tersebut lebih menguntungkan karena dapat menghemat waktu dan biaya dan menjaga nama baik kedua belah pihak.

\section{B. Saran}

1. LKM Syariah dalam proses penyaluran pernbiayaan disarankan agar lebih selektif dalam memberikan pembiayaan kepada debitur, serta melaksanakan semua yang telah dimuat di dalarn akad perjanjian.

2. Debitur penerima pembiayaan disarankan untuk berupaya agar selalu berusaha melakukan pembayaran angsuran tepat pada waktunya guna menjaga nama baik dimata LKM Syariah dan tidak menyalahgunakan modal usaha serta memamfaatkan pembiayaan sesuai dengan perjanjian agar nantinya dapat mengembalikan pernbiayaan tepat pada waktunya.

\section{DAFTAR PUSTAKA}

\section{A. Buku-buku}

Abdul Kadir Muhammad, Hukum Perikatan, Citra Aditya Bakti, Bandung, 1992. Ichsan Ahmad, Hukum Perdata, I.B, PT. Pembimbing Masa, Jakarta, 1969.

Latifa M. Algoud dan Mevyn K. Lewis. Perbankan Syari'ah: Prinsip, Praktek dan Prospek, Serambi, Jakarta, 2003.

M. Amin Azis, Mengembangkan Bank Islam di Indonesia, Buku II, Bangkit, Jakarta, 1990.

Mariam Darns Badrulzaman, Pembentukan Hukum Nasional dan Permasalahannya, Alumni, Bandung, 1980.

Muhammad Syafi'i Antonio, Bank Syariah dari Teori ke Praktik, Gema Insani, Jakarta 2001.

Muhammad Yahya Harahap, Segi-Segi Hukum Perjanjian, Alumni, Bandung, 1982

Munir Fuady, Hukum Perbankan Modern, Citra Aditya Bakti, Bandung, 1999.

Mariam Darns Badrulzaman, Pembentukan Hukum Nasional dan Permasalahannya, Alumni, Bandung, 1980.

Nindyo Pramono, Beberapa Aspek Koperasi pada Umumnya dan Koperasi Indonesia didalam Perkembangannya, TPK Gunung Mulia, Yogyakarta, 1996.

R_ Subekti, Hukum Perjanjian, cetakan ke IX. PT. Intermasa, Jakarta 
Jaminan-Jaminan Untuk Pemberian Kredit Menurut Hukum Indonesia, Alumni Bandung, 1982.

Rachmadi Usman, Aspek-Aspek Hukum Perbankan Islam di Indonesia,. PT. Citra Aditya Bakti, Bandung.

Ridwan Syahrani, Perjanjian Dari Aspek Yuridis, Pradyna Paramita, 1985.

Salim HS, Pengantar Hukum Perdata Tertulis, Sinar Grafika, Jakarta, 2002.

Hukum Kontrak (Teori dan Teknik Penyusunan Kontrak), sinar Grafika, Jakarta, 2006

Syayyid Sabiq, Fiqih Sunnah, Al-Maarif, Bandung, 1993,
Soejono Soekonto, Faktor-faktor J'ong Mempengoruhi Penegakan Hukum. PT. Raja Grafindo, Jakrta, 1983.

Sudikno Mertukusumo, Hukum Acara Perdata Indonesia. Liberty. Yokyakarta 1989

Wiryono prodjodikoro, Asas-Asas Hukum Perjanjian, Sumur, Bandung, 1973.

Warkum Sumitro, Asas-asas Perbankan Islam dan Lembaga Terkait, Raja grafindo, Jakrta, 1996.

\section{B. Peraturan Pcrundang-undangan}

1. Kitab Undang-undang Hukum Perdata (KUH Perdata)

2. Undang-undang No. 17 Tahun 2012 Tentang Perkoperasian. 